\title{
KARAKTERISTIK INDEKS MASSA TUBUH DAN JENIS KELAMIN PASIEN HIPERTENSI DI RS IBNU SINA MAKASSAR
}

\author{
Rachmat Faisal Syamsu ${ }^{1}$, Siska Nuryanti ${ }^{2}$, Muhammad Yatsrib Semme ${ }^{3}$
}

1.Dosen Bagian IKM-IKK, Fakultas Kedokteran, Universitas Muslim Indonesia, Indonesia 2.Laboratorium Mikrobiologi Farmasi, Fakultas Farmasi, Universitas Muslim Indonesia, Indonesia 3. Mahasiswa Program Profesi Dokter, Fakultas Kedokteran, Universitas Muslim Indonesia, Indonesia

\section{Article Info}

Article history:

Received 16-04-2021

Revised 04-09-2021

Accepted 04-09-2021

\section{Keywords:}

Indeks Massa Tubuh (IMT)

Jenis Kelamin

Hipertensi

RS Ibnu Sina \begin{abstract}
Hypertension, commonly referred to as high blood pressure, is a global health problem in Indonesia because of its high prevalence, although it varies in different countries. In Indonesia, hypertension is found in 83 per 1000 household members. The majority of high blood pressure increases with the presence of risk factors such as; Age, lack of exercise / physical activity, genetic factors and family history, body weight/obesity, sodium intake, alcohol consumption, smoking, stress. This study is a descriptive design using an observational approach to describe the characteristics of the risk factors for the Body Mass Index (BMI) and the gender of hypertension patients at Ibnu Sina Hospital for November 2018. The sampling technique used the total sampling technique with a complete sample size of 26 people. The results showed that the gender characteristics of hypertension sufferers showed that the number of female patients (16 people) was more than that of male patients (10 people). And the attributes of BMI in patients with hypertension found that the number of patients with normal nutritional status (13 people) was the most compared to another nutritional status.

Abstrak

Hipertensi atau secara awam disebut sebagai tekanan darah tinggi adalah masalah kesehatan global, termasuk di Indonesia karena prevalensinya tinggi, meskipun berbeda-beda di berbagai negara. Di Indonesia, hipertensi didapatkan pada 83 per 1000 anggota rumah tangga. Prevalensi tekanan darah tinggi meningkat dengan seiring dengan adanya faktor resiko seperti ; Usia, Kurang olahraga/aktifitas fisik, Faktor genetik dan riwayat keluarga, Berat badan/obesitas, Asupan natrium, Konsumsi alkohol, merokok, Stress. Penelitian ini adalah desain deskriptif dengan menggunakan pendekatan observasional untuk melihat gambaran karakteristik faktor resiko Indeks Massa Tubuh (IMT) dan jenis kelamin pasien Hipertensi di RS Ibnu Sina periode November 2018. Teknik pengambilan sampel menggunakan teknik total sampling. dengan jumlah total sampel 26 orang. Didapatkan hasil, karakteristik jenis kelamin pada penderita Hipertensi didapatkan jumlah pasien wanita (16 orang) lebih banyak dibandingkan pasien laki-laki (10 orang). Dan karakteristik IMT pada penderita Hipertensi didapatkan jumlah pasien dengan status gizi normal (13 orang) paling banyak dibandingkan status gizi yang lainnya
\end{abstract}

Corresponding Author:

Rachmat Faisal Syamsu

Department of Community Medicine, Faculty of Medicine

Universitas Muslim Indonesia

Jln. Palm Merah No 12, Makassar, South Sulawesi, Indonesia 
e-ISSN: 2541-4542

\section{PENDAHULUAN}

Hipertensi atau secara awam disebut sebagai tekanan darah tinggi adalah masalah kesehatan global, termasuk di Indonesia karena prevalensinya tinggi, meskipun berbedabeda di berbagai negara. Tekanan darah tinggi akan sangat berbahaya karena membuat jantung bekerja terlalu keras, mengeraskan dinding arteri dan dapat menyebabkan perdarahan otak atau menyebabkan yang tidak baik bagi fungsi ginjal atau bahkan tidak dapat berfungsi lagi. Jika tidak dikendalikan, tekanan darah tinggi dapat menyebabkan penyakit jantung, ginjal, stroke, dan kebutaan. ${ }^{1,2}$

Menurut WHO dan the International Society of Hypertension (ISH), saat ini terdapat 600 juta penderita hipertensi diseluruh dunia, dan 3 juta di antaranya meninggal setiap tahunnya.Diperkirakan sekitar $80 \%$ kenaikan kasus hipertensi terutama di negara berkembang tahun 2025, dari sejumlah 639 juta kasus di tahun 2000, di perkirakan menjadi 1,15 milyar kasus di tahun 2025.Prediksi ini didasarkan pada angka penderita hipertensi saat ini dan pertambahan penduduk saat ini. Hal ini diperparah dengan 7 dari setiap 10 penderita tersebut tidak mendapatkan pengobatan secara adekuat. ${ }^{3,4}$

Di Indonesia, hipertensi didapatkan pada 83 per 1000 anggota rumah tangga. Prevalensi tekanan darah tinggi meningkat dengan seiring dengan peningkatan usia. Banyaknya penderita hipertensi diperkirakan 15 juta orang tetapi hanya $4 \%$ yang merupakan hipertensi terkontrol. Prevalensi 6-15\% pada orang dewasa, 50\% diantaranya tidak menyadari sebagai penderita hipertensi sehingga mereka cenderung untuk menjadi hipertensi berat karena tidak menghindari dan tidak mengetahui faktor risikonya, dan 90\% merupakan hipertensi esensial. Hal itu merupakan masalah kesehatan dengan prevalensi yang tinggi, yaitu sebesar 25,8\%, sesuai dengan data Riskesdas 2013.

Di Sulawesi Selatan sendiri penderita hipertensi terdapat kurang lebih $29 \%$ dari total penduduk yang ada. Angka ini akan terus bertambah apabila tidak diimbangi dengan edukasi dan terapi hipertensi yang adekuat., ${ }^{4,5,6}$.

Faktor risiko adalah kondisi atau perilaku yang meningkatkan kesempatan anda untuk mengembangkan penyakit. Faktor risiko terjadinya hipertensi dapat dikelompokkan faktor risiko yang tidak dapat dimodifikasi, seperti usia, gender, ras; dan yang dapat dimodifikasi, yaitu gaya hidup. Penelitian yang telah dilakukan menunjukkan bahwa modifikasi gaya hidup dapat menurunkan tekanan darah serta meningkatkan efektivitas terapi farmakologik. ${ }^{8}$ Beberapa faktor resiko kejadian hipertensi antara lain: ${ }^{6}$ 
1) Usia

Usia cenderung menjadi faktor risiko yang sangat kuat. Angka kejadian(prevalensi) Hipertensi pada orang usia muda masa kuliah berkisar 2$3 \%$,sementara prevalensi Hipertensi pada manula berkisar $65 \%$ atau lebih. Tekanan darah cenderung naik seiring bertambahnya usia, risiko untukmeningkatnya penyakit Hipertensi akan lebih tinggi juga seiring bertambahnya usia.

2) Kurang olahraga/aktifitas fisik

Olahraga teratur adalah suatu kebiasaan yang memberikan banyakkeuntungan seperti berkurangnya berat badan, tekanan darah, kolesterol sertapenyakit jantung. Dalam kaitannya dengan Hipertensi, olahraga teratur dapatmengurangi kekakuan pembuluh darah dan meningkatkan daya tahan jantung danparu-paru sehingga dapat menurunkan tekanan darah.

3) Faktor genetik dan riwayat keluarga

Hipertensi esensial merupakan penyakit multifaktorial yang dipengaruhifaktor genetik dan lingkungan. Pengaruh genetik ini sangat bervariasi, dilaporkansekitar $15 \%$ pada populasi tertentu sampai dengan $60 \%$ pada populasi lainnya.Peranan faktor genetik pada etiologi Hipertensi didukung oleh penelitian yangmembuktikan bahwa Hipertensi terjadi di antara keluarga terdekat walaupundalam lingkungan yang berbeda.

4) Berat badan/obesitas

Seseorang lebih berisiko mengalami pra-Hipertensi maupun menderitaHipertensi jika memiliki berat badan berlebih atau obesitas. Istilah "berat badanberlebih" dan "obesitas" merujuk pada berat badan yang lebih besar dari apa yangdianggap sehat untuk tinggi badan tertentu.

5) Asupan natrium

Diet yang terlalu tinggi natrium dan terlalu rendah kalium dapatmeningkatkan risiko terserang Hipertensi. Makan terlalu banyak unsur natriumdalam garam dapat meningkatkan tekanan darah. Sebagian besar natrium kitadapatkan berasal dari makanan olahan dan makanan restoran. Tidak cukup makankalium juga bisa meningkatkan tekanan darah. Zat kalium dapat ditemukan padamakanan seperti pisang, kentang, kacang-kacangan, dan yogurt. 
6) Konsumsi alkohol dan merokok

Hipertensi akan meninggi jika meminum alkohol lebih dari tiga kali dalamsehari. Dan mengkonsumsi alkohol sedang (moderate) diperkirakan punya efek protektif.

7) Stress

Stress terjadi karena ketidakmampuan mengatasi ancaman yang dihadapimental, fisik, emosional, dan spiritual seseorang. Kondisi tersebut pada suatu saatakan mempengaruhi kesehatan fisik seseorang. Hubungan stress denganHipertensi, diduga terjadi melalui saraf simpatis. Peningkatan aktivitas sarafsimpatis dapat meningkatkan tekanan darah secara intermitten (tidak menentu) Apabila stress berkepanjangan, dapat mengakibatkan tekanan darah menetap tinggi.

\section{METODE PENELITIAN}

Penelitian yang dilakukan adalah penelitian deskriptif dengan menggunakan pendekatan observasional untuk melihat gambaran karakteristik faktor resiko Indeks Massa Tubuh (IMT) dan jenis kelamin pasien Hipertensi di RS Ibnu Sina periode November 2018. Teknik pengambilan sampel menggunakan teknik total sampling. Dimana seluruh populasi yang masuk dalam kriteria dijadikan sebagai sampel untuk penelitian ini berjumlah 26 orang.

\section{HASIL DAN PEMBAHASAN}

\subsection{Hasil Penelitian}

Karakteristik sampel berikut ini menjelaskan mengenai distribusifrekuensi dari setiap variabel terkait mengenai IMT dan jenis kelaminpasien Hipertensi di RS Ibnu Sina periode November 2018. Adapun hasil analisis data tersebut sebagai berikut:

Tabel 1. Distribusi frekuensi pasien Hipertensi berdasarkan jenis kelamin

\begin{tabular}{lll}
\hline Jenis Kelamin & Jumlah & Persentase \\
\hline Laki-Laki & 10 & $\mathbf{3 8 , 4 6 \%}$ \\
Perempuan & 16 & $\mathbf{5 1 , 5 4} \%$ \\
\hline Total & $\mathbf{2 6}$ & $\mathbf{1 0 0} \%$
\end{tabular}

Sumber : Rekam Medik RS Ibnu Sina November 2018 diolah MS Excel 2010

Berdasarkan Tabel diatas dapat diketahui bahwa jumlah pasien laki - laki dengan Hipertensi yaitu berjumlah 10 orang $(38,46 \%)$ dan jumlah pasien perempuan dengan Hipertensi yaitu berjumlah 16 orang $(51,54 \%)$. 
Tabel 2. Distribusi frekuensi pasien Hipertensi berdasarkan IMT

\begin{tabular}{lll}
\hline IMT & Frekuensi & Persentase \\
\hline Underweight & $\mathbf{2}$ & $\mathbf{7 , 6 9} \%$ \\
Normal & $\mathbf{1 3}$ & $\mathbf{5 0 , 0 0} \%$ \\
Overweight & $\mathbf{4}$ & $\mathbf{1 5 , 3 8} \%$ \\
Obesitas I & $\mathbf{7}$ & $\mathbf{2 6 , 9 2} \%$ \\
Obesitas II & $\mathbf{0}$ & $\mathbf{0 , 0 0} \%$ \\
\hline Total & $\mathbf{2 6}$ & $\mathbf{1 0 0} \%$ \\
Sumber : Rekam MedikRS Ibnu Sina November 2018 diolah MS Excel 2010
\end{tabular}

3.1 Hasil Penelitian

Karakteristik sampel berikut ini menjelaskan mengenai distribusifrekuensi dari setiap variabel terkait mengenai IMT dan jenis kelaminpasien Hipertensi di RS Ibnu Sina periode November 2018. Adapun hasil analisis data tersebut sebagai berikut:

Tabel 1. Distribusi frekuensi pasien Hipertensi berdasarkan jenis kelamin

\begin{tabular}{llc}
\hline Jenis Kelamin & Jumlah & Persentase \\
\hline Laki-Laki & 10 & $38,46 \%$ \\
Perempuan & 16 & $51,54 \%$ \\
\hline Total & 26 & 100
\end{tabular}

Sumber : Rekam Medik RS Ibnu Sina November 2018 diolah MS Excel 2010

Berdasarkan Tabel diatas dapat diketahui bahwa jumlah pasien laki - laki dengan Hipertensi yaitu berjumlah 10 orang $(38,46 \%)$ dan jumlah pasien perempuan dengan Hipertensi yaitu berjumlah 16 orang $(51,54 \%)$.

Tabel 2. Distribusi frekuensi pasien Hipertensi berdasarkan IMT

\begin{tabular}{lll}
\hline IMT & Frekuensi & Persentase \\
\hline Underweight & $\mathbf{2}$ & $\mathbf{7 , 6 9} \%$ \\
Normal & $\mathbf{1 3}$ & $\mathbf{5 0 , 0 0 \%}$ \\
Overweight & $\mathbf{4}$ & $\mathbf{1 5 , 3 8 \%}$ \\
Obesitas I & $\mathbf{7}$ & $\mathbf{2 6 , 9 2} \%$ \\
Obesitas II & $\mathbf{0}$ & $\mathbf{0 , 0 0} \%$ \\
\hline Total & $\mathbf{2 6}$ & $\mathbf{1 0 0} \%$ \\
\hline \multicolumn{1}{c}{ Sumber $:$ Rekam MedikRS Ibnu Sina November 2018 diolah MS Excel 2010 }
\end{tabular}


Berdasarkan Tabel 5.2 dapat diketahui bahwa jumlah pasien Hipertensi dengan IMT yang underweight sebanyak 02 orang (7,96 \%), normal sebanyak 13 orang (50 $\%)$, overweight sebanyak 4 orang $(15,38 \%)$, obesitas I sebanyak 7 orang $(26,92 \%)$, dan obesitas II sebanyak 0 orang $(0 \%)$.

\section{PEMBAHASAN}

Berdasarkan Tabel 5.2 dapat diketahui bahwa jumlah pasien Hipertensi dengan IMT yang underweight sebanyak 02 orang (7,96 \%), normal sebanyak 13 orang (50\%), overweight sebanyak 4 orang $(15,38 \%)$, obesitas I sebanyak 7 orang $(26,92 \%)$, dan obesitas II sebanyak 0 orang $(0 \%)$.

Berdasarkan hasil penelitian, pasien Hipertensi wanita lebih banyak $(51,54$ $\%)$ dibandingkan pria (38,46\%). Dari hasil Analisis data Riskesdas didapatkan bahwa prevalensi hipertensi berdasarkan jenis kelamin tahun 2007 maupun tahun 2013, perempuan lebih tinggi dibanding laki-laki. Sehingga perempuan lebih berisiko untuk menderita Hipertensi.Hal ini sesuai dengan penelitian menurut Singalingging (2011), didapatkan bahwa rata-rata perempuan akan mengalami peningkatan risiko tekanan darah tinggi (hipertensi) setelah menopouse yaitu usia diatas 45 tahun. Perempuan yang belum menopause dilindungi oleh hormon estrogen yang berperan dalam meningkatkan kadar High Density Lipoprotein (HDL). Kadar kolesterol HDL rendah dan tingginya kolesterol LDL (Low Density Lipoprotein) mempengaruhi terjadinya proses aterosklerosis. Setelah umur 55 tahun perempuan melampaui laki-laki sebabnya tidak terlalu jelas tetapi dapat disebabkan karena perempuan dilindingi hormon kewanitaan selama masa produktivitas 22

Proporsi laki-laki dengan hipertensi pada umur <45 tahun lebih banyak dibandingkan dengan perempuan. Setelah umur 45 tahun resiko pria dan wanita aterhadap penyakit hipertensi relative sama, Sedangkan pada usia $>55$ tahun resiko mengalami hipertensi lebih rentan terjadi pada wanita dibandingkan pria. Terjadinya hipertensi atau peningkatan tekanan darah dapat disebabkan oleh beberapa hal diantaranya adalah obesitas, genetik, diet tinggi natrium, umur, aktivitas olah raga, dan peningkatan konsumsi alkohol. Proses penuaan mempengaruhi perubahan fisik dan mental yang dapat mengakibatkan penurunan daya tahan tubuh sehingga semakin tua usia maka berisiko mengakibatkan timbulnya berbagai macam penyakit, salah satunya adalah penyakit hipertensi yang sering ditemukan pada lansia23 
Berdasarkan IMT, pasien Hipertensi dengan status gizi "normal" lebih banyak, yaitu $50 \%$ dibandingkan kelompok status gizi lainnya. Hasil penelitian ini tidak jauh berbeda dengan penelitian Hendraswari DE tahun 2008, mendapatkan pasien hipertensi lebih banyak dengan status indeks massa tubuh normal sebanyak 185 dari 257 penderita hipertensi.

Hal ini berbeda dengan teori dan data yang menjelasan bahwa obesitas merupakan salah satu faktor risiko terjadinya Hipertensi. Menurut Frisoli (2011), pada orang yang obesitas terjadi peningkatan kerja pada jantung untuk memompa darah. Berat badan berlebihan menyebabkan bertambahnya volume darah dan perluasan sistem sirkulasi. Makin besar massa tubuh, makin banyak pula suplai darah yang dibutuhkan untuk memasok oksigen dan nutrisi ke jaringan tubuh. Hal ini mengakibatkan volume darah yang beredar melalui pembuluh darah akan meningkat sehingga tekanan pada dinding arteri menjadi lebih besar.

Penelitian lain yang dilakukan oleh Delmi Sulastri dkk, mengenai kejadian hipertensi pada masyarakat etnik Minangkabau di Kota Padang, menyimpulkan bahwa terdapat hubungan antara Obesitas dengan kejadian hipertensi faktor risiko terjadinya hipertensi, dimana responden yang mengalami obesitas sentral berisiko untuk hipertensi 2,72 kali jika dibandingkan dengan responden yang tidak mengalami obesitas.. Berdasarkan penelitian agustina, 2015 menyatakan bahwa ada hubungan antara IMT dan tekanan darah pada penderita hipertensi

Penelitian yang dilakukan oleh Hendrik di Fakultas Kedokteran Universitas Sumatra Utara tahun 2012 menunjukan bahwa kenaikan nilai IMT diikuti dengan kenaikan tekanan darah. Artinya semakin tinggi nilai IMT seseorang maka peluang untuk terkena hipertensi semakin tinggi pula. Walaupun demikian, faktor terjadinya hipertensi pada sampel penelitian ini mungkin saja tidak semata-mata disebabkan faktor IMT melainkan factor faktor lainnya seperti umur dan pola hidup tidak sehat lainnya (kebiasaan olahraga)

Berdasarkan hasil penelitian, pasien Hipertensi wanita lebih banyak $(51,54 \%)$ dibandingkan pria $(38,46 \%)$. Dari hasil Analisis data Riskesdas didapatkan bahwa prevalensi hipertensi berdasarkan jenis kelamin tahun 2007 maupun tahun 2013, perempuan lebih tinggi dibanding laki-laki. Sehingga perempuan lebih berisiko untuk menderita Hipertensi.Hal ini sesuai dengan penelitian menurut Singalingging (2011), didapatkan bahwa rata-rata perempuan akan mengalami peningkatan risiko tekanan 
darah tinggi (hipertensi) setelah menopouse yaitu usia diatas 45 tahun. Perempuan yang belum menopause dilindungi oleh hormon estrogen yang berperan dalam meningkatkan kadar High Density Lipoprotein (HDL). Kadar kolesterol HDL rendah dan tingginya kolesterol LDL (Low Density Lipoprotein) mempengaruhi terjadinya proses aterosklerosis. Setelah umur 55 tahun perempuan melampaui laki-laki sebabnya tidak terlalu jelas tetapi dapat disebabkan karena perempuan dilindingi hormon kewanitaan selama masa produktivitas ${ }^{22}$

Proporsi laki-laki dengan hipertensi pada umur <45 tahun lebih banyak dibandingkan dengan perempuan. Setelah umur 45 tahun resiko pria dan wanita aterhadap penyakit hipertensi relative sama, Sedangkan pada usia > 55 tahun resiko mengalami hipertensi lebih rentan terjadi pada wanita dibandingkan pria. Terjadinya hipertensi atau peningkatan tekanan darah dapat disebabkan oleh beberapa hal diantaranya adalah obesitas, genetik, diet tinggi natrium, umur, aktivitas olah raga, dan peningkatan konsumsi alkohol. Proses penuaan mempengaruhi perubahan fisik dan mental yang dapat mengakibatkan penurunan daya tahan tubuh sehingga semakin tua usia maka berisiko mengakibatkan timbulnya berbagai macam penyakit, salah satunya adalah penyakit hipertensi yang sering ditemukan pada lansia ${ }^{23}$

Berdasarkan IMT, pasien Hipertensi dengan status gizi "normal” lebih banyak, yaitu $50 \%$ dibandingkan kelompok status gizi lainnya. Hasil penelitian ini tidak jauh berbeda dengan penelitian Hendraswari DE tahun 2008, mendapatkan pasien hipertensi lebih banyak dengan status indeks massa tubuh normal sebanyak 185 dari 257 penderita hipertensi.

Hal ini berbeda dengan teori dan data yang menjelasan bahwa obesitas merupakan salah satu faktor risiko terjadinya Hipertensi. Menurut Frisoli (2011), pada orang yang obesitas terjadi peningkatan kerja pada jantung untuk memompa darah. Berat badan berlebihan menyebabkan bertambahnya volume darah dan perluasan sistem sirkulasi. Makin besar massa tubuh, makin banyak pula suplai darah yang dibutuhkan untuk memasok oksigen dan nutrisi ke jaringan tubuh. Hal ini mengakibatkan volume darah yang beredar melalui pembuluh darah akan meningkat sehingga tekanan pada dinding arteri menjadi lebih besar.

Penelitian lain yang dilakukan oleh Delmi Sulastri dkk, mengenai kejadian hipertensi pada masyarakat etnik Minangkabau di Kota Padang, menyimpulkan bahwa terdapat hubungan antara Obesitas dengan kejadian hipertensi faktor risiko terjadinya 
hipertensi, dimana responden yang mengalami obesitas sentral berisiko untuk hipertensi 2,72 kali jika dibandingkan dengan responden yang tidak mengalami obesitas.. Berdasarkan penelitian agustina, 2015 menyatakan bahwa ada hubungan antara IMT dan tekanan darah pada penderita hipertensi

Penelitian yang dilakukan oleh Hendrik di Fakultas Kedokteran Universitas Sumatra Utara tahun 2012 menunjukan bahwa kenaikan nilai IMT diikuti dengan kenaikan tekanan darah. Artinya semakin tinggi nilai IMT seseorang maka peluang untuk terkena hipertensi semakin tinggi pula. Walaupun demikian, faktor terjadinya hipertensi pada sampel penelitian ini mungkin saja tidak semata-mata disebabkan faktor IMT melainkan factor faktor lainnya seperti umur dan pola hidup tidak sehat lainnya (kebiasaan olahraga)

\section{KESIMPULAN}

Hasil penelitian menunjukkan bahwa karakteristik jenis kelamin pada penderita Hipertensi didapatkan jumlah pasien wanita lebih banyak dibandingkan pasien laki-laki dan karakteristik IMT pada penderita Hipertensi didapatkan jumlah pasien dengan status gizi normal paling banyak dibandingkan status gizi yang lainnya.

\section{UCAPAN TERIMA KASIH}

Terima kasih kepada semua pihak yang telah mendukung dalam peneltian ini. Pihak Rumah Sakit Ibnu Sina YW-UMI, Fakultas Kedokteran UMI, dan Fakultas Farmasi UMI.

\section{DAFTAR RUJUKAN}

1. Riantono L. 5 Rahasia Penyakit Kardiovaskular. Jakarta: Badan Penerbit Fakultas Kedokteran Universitas Indonesia; 2013.

2. National Heart, Lung and BI. Lowering Your Blood Pressure With DASH. NIH Public Access. 2015:64. doi:10.1037/e566492010-001.

3. Rahajeng E, Tuminah S. Prevalensi Hipertensi dan Determinannya di Indonesia. Maj Kedokt Indones. 2009;59(12):580-587.

4. Amiruddin AAR. Hipertensi dan faktor risikonya dalam kajian epidemiologi. 2007. https://ridwanamiruddin.wordpress.com/2007/12/08/hipertensi-dan-faktor-risikonyadalam-kajian-epidemiologi/. Published 2007. 
5. Appel LJ, Brands MW, Daniels SR, Karanja N, Elmer PJ, Sacks FM. Dietary approaches to prevent and treat hypertension: A scientific statement from the American Heart Association. Hypertension. 2006;47(2):296-308. doi:10.1161/01.HYP.0000202568.01167.B6.

6. Ridjab D a. Modifikasi Gaya Hidup dan Tekanan Darah. :159-166.

Widyanto, F.C, dan Triwibowo, C., 2013. Trend Disease. Jakarta : CV. Trans Info Media

7. Bell K, Twiggs J, Olin BR. Hypertension: The Silent Killer: Updated JNC-8 Guideline Recommendations. Alabama Pharm Assoc. 2015:1-8. doi:0178-0000-15104-H01-P.

8. Kumala M. Peram Diet Dalam Pencegahan dan Terapi Hipertensi. DAMIANUS J Med. 2014;13(1):50-61.

9. U.S. DEPARTMENT OF HEALTH AND HUMAN SERVICES. Your Guide to Lowering Blood Pressure. Blood Press. 2003:8-11. https://www.nhlbi.nih.gov/files/docs/public/heart/hbp_low.pdf.

10. Kresnawan T. ASUHAN GIZI PADA HIPERTENSI 1 Instalasi Triyani Kresnawan 1 Gizi RSUPN Dr. Cipto Mangunkusumo, Jakarta. Blood Press. 2011;34(2):143-147.

11. Pustaka T. Tata Laksana Hipertensi. 2012;39(4):251-255.

12. Peter Kabo. Bagaimana Menggunakan Obat - Obat Kardiovaskular Secara Rasional. Jakarta: Badan Penerbit Fakultas Kedokteran Universitas Indonesia; 2014.

13. Harahap, Heryudarini; Hardinsyah; Setiawan, Budi; Effendi I. hubungan Indeks Massa Tubuh, Jenis Kelamin, Usia, Golongan Darah dan Riwayat Keturunan dengan Tekanan darah pada Pegawai Negeri Sipil di Pekan Baru. 2008;31(2):55. http://download.portalgaruda.org/article.php?article=87061 \&val=4888.

14. Esc C, Cifkova R, Bo M, et al. 2013 ESH / ESC Guidelines for the management of arterial hypertension The Task Force for the management of arterial hypertension of the European Society of Hypertension ( ESH ) and of the European Society. 2013:2159-2219. doi:10.1093/eurheartj/eht151.

15. Prevention C for DC and. High Blood Pressure. CDC. 2014. http://www.cdc.gov/bloodpressure/index.htm.

16. Research M foundation for MeE and. High Blood Pressure (HTN). Mayo Clin. 2014. http://www.mayoclinic.org/diseases-conditions/highbloodpressure/basics/definition/con-20019580. 
17. Sylvia A P. Patofisiologi : Konsep Klinis Proses - Proses Penyakit. 6th ed. Jakarta: EGC; 2005.

18. Panggabean M. Penyakit Jantung Hipertensi. In: Ilmu Ajar Penyakit Dalam. Ed6 Jilid . Jakarta: Interna Publishing; 2015.

19. Edition H. Management of Hypertension. 2008;08(February).

20. Association $\mathbf{J}$ of the AM. JNC 8 Guideline for the Management hypertension of Adult. 2013. http://jama.jamanetwork.com/article.aspx?articleid=1791497.

21. Agustina R, Raharjo BB. Faktor Risiko yang Berhubungan dengan Kejadian Hipertensi Usia Produktif (25-54 Tahun). Unnes J Public Heal [Internet]. 2015 Oct ;4(4). Available from: https://doaj.org/article/2e2656af4fdd4 a968968a3b37587bb6d 10. Sudoyo A, B S, Alwi I, S

22. Hendraswari DE. Beberapa faktor yang berhubungan dengan hipertensi di kelurahan Jagakarsa tahun 2007. Fakultas Kesehatan Masyarakat Universitas Indonesia, Jakarta, 2008: 1-22.

23. Wahyuningsih, Astuti, E. Faktor yang mempengaruhi hipertensi pada usia lanjut. JNKI,1(3): 71-75. 2013. 24. Tamher \& Noorkasiani. Kesehatan Usia Lanjut dengan Pendekatan Asuhan Keperawatan. Jakarta: Salemba Medika. 2009.

24. Hendrik. 2012. Hubungan Indeks Massa Tubuh Dengan Tekanan Darah Pada Mahasiswa Fakultas Kedokteran Universitas Sumatera Utara. Skripsi: Fakultas Kedokteran Universitas Sumatera Utara. 